\title{
ASSESSMENT OF HEAVY METALS IN OKRA (Abelmoschus esculentus) CULTIVATED THROUGH IRRIGATION, IN MAIDUGURI, NIGERIA
}

\author{
${ }^{* 1}$ Bukar P. H. and ${ }^{2}$ Onoja M. A.
}

\author{
${ }^{*}$ Department of Science Laboratory Technology, Nigerian Institute of Leather and Science Technology Zaria. \\ Phone: 08053646818 Email: paul.hena@yahoo.com. \\ ${ }^{2}$ Department of Physics, Ahmadu Bello University Zaria. \\ Phone: 08023635535 Email: gtob2014@gmail.com
}

\begin{abstract}
The contamination of the environment with heavy metals is one of the challenges that constitute Nigeria's environmental problem with urbanization being one of the major causes; due to the unavailability of proper waste dumpsites and landfills for infrastructural development thereby resulting in the polluting rivers and streams. The cultivation of vegetables along channels and rivers that transcend major cities have been a source of concern globally in recent decades due to accumulation of heavy metals and introduction of heavy metals into the food chain. This study therefore assessed the level of concentration of heavy metals namely; Aluminum, Iron, Lanthanum, Manganese, Chromium, Rubidium, Antimony, Scandium, Barium, Samarium and Zinc in Okra (Abelmoschus esclentus) samples obtained on farmlands along the bank of river Ngadda and Alau dam cultivated through irrigation. The samples were analyzed using instrumental neutron activation analysis (INAA) analytical technique with the aim of assessing their level of accumulation with heavy metals. The objective was to ascertain the food safety status of the vegetable by comparing the values obtained with maximum permissible limit (MPL) recommended by FAO/WHO for vegetables. The study results show that the concentration levels ranged from below detection limit (BDL) for Aluminum, Chromium, and Antimony (843 \pm 16 ppm, $1.3 \pm 0.2 \mathrm{ppm}$ and $0.26 \pm 0.03$ ppm respectively) to Barium (7 \pm 1.0 to $12 \pm 1.0$ ppm, Iron $11 \pm$ 0.4 to $303 \pm 36 \mathrm{ppm})$, Lanthanum $(0.203 \pm 0.03$ to $1.93 \pm 0.05 \mathrm{ppm})$, Manganese $(22.9 \pm 0.2$ to $40.2 \pm 0.2 \mathrm{ppm})$, Rubidium ( $7 \pm 1$ to $13 \pm 1$ ppm), Scandium ( $0.02 \pm 0.00$ to $0.05 \pm 0.01 \mathrm{ppm})$, Samarium (0.02 \pm 0 to $0.24 \pm 0.01 \mathrm{ppm})$, and Zinc (8 \pm 1.0 to $24 \pm 0.1 \mathrm{ppm})$. This result also indicates that the maximum concentration value of Manganese exceeds the 25.95 ppm value of MPL recommended by FAO/WHO for vegetables therefore the consumption of Okra (Abelmoschus esclentus) cultivated from the study site has a potential health risk due to the presence of Manganese above recommended value.
\end{abstract}

Keywords: Assessment, accumulation, heavy metals, irrigation, Okra (Abelmoschus esclentus)

LICENSE: This work by Open Journals Nigeria is licensed and published under the Creative Commons Attribution License 4.0 International License, which permits unrestricted use, distribution, and reproduction in any medium, provided this article is duly cited.

COPYRIGHT: The Author(s) completely retain the copyright of this published article.

OPEN ACCESS: The Author(s) approves that this article remains permanently online in the open access (OA) mode.

QA: This Article is published in line with "COPE (Committee on Publication Ethics) and PIE (Publication Integrity \& Ethics)". 
In recent years, there has been an increasing ecological and global public health concern associated with environmental contamination by heavy metals. (Tchounwou et al., 2014). Industrial and domestic effluents constitute the largest sources of heavy metals which contribute to the steady increase of metallic contaminant in aquatic and terrestrial environment in most part of the world (Jibrin and Adewuyi, 2008; Oshodi and Ipinmoroti, 1990; Sekhar, 2003; Hamid et al., 2017). It has also been observed that heavy metals and other pollutants are continuously discharged into the soils on a daily basis through land waste disposal, input from the atmosphere, metals from vehicular exhaust emissions and irrigation by municipal waste water (Uwah et al., 2009; Matthews-Amune, 2018). Thus, pollution of the river water in big cities of developing countries are common because waste water treatment is not given the necessary priority it deserves hence industrial waste and domestic sewage are discharged into nearby water bodies without treatment due to disposal needs (Asonye et al., 2009; Dan'azumi and Bichi, 2010).

Heavy metals have high density and mostly toxic in nature for human, plants and animals regardless of their concentrations due to their accumulation in food chain and persisted in nature (LWTAP 2004; Oves, et al., 2012; Ahmed et al., 2019). Therefore, food safety issues and potential health risks make this as one of the most serious environmental concerns (Cui et al., 2004) because when such water is used for cultivation of crops for a long period, these heavy metals may accumulate in soil. An investigation by (Mortan et al., 2004 and Mmolawa et al., 2011) showed that considerable concentrations of heavy metals were found along major roads in Mexico City and Botswana respectively. Cultivated crops such as vegetables on contaminated soils could absorbed the heavy metals by through their root systems and transported to various parts of the plants reaching toxic levels as vegetables are known to accumulate heavy metals in their edible parts (Singh et al 2010, Khan, 2015) more so, this could be a primary route of human exposure to metal toxicants (Nabulo, 2010) hence heavy metals are viewed as an international problem due to its effects on the ecosystem in most countries. (Egila, et al., 2019).

Research has shown that human exposure to heavy metal and intake were basically through food, inhalation and dermal contact (Khan, et al., 2014; Ferre- Huguet et al., 2008; Kim, et al., 2009; Martorell, et al., 2011), Surveys have also shown that continuous consumption of concentrations of heavy metals through foodstuffs lead to large accumulations of the metals in the kidney and liver of humans causing disruption of numerous body processes, leading to cardiovascular, nervous, kidney and bone diseases (Sabina Braun 2015, Oladebeye, 2017).

Okra are vegetables that are cultivated and consumed by many people living in northern part of Nigeria, therefore they form an essential part of the indigenes diet and as food crops they are generally consumed for their nutrition value (Ramteke, et al., 2016; Hang Zhou et al., 2016; Deribachew et al., 2015) and they may contain a number of essential and toxic metals (Yang et al., 2011; Waqas et al., 2015).

The okra vegetables cultivated along the bank of river Ngadda and Alau dam during dry season were suspected to be contaminated with metal pollutants due to the fact that the soil and water might have mixed up with metal contaminants from solid waste deposal, sludge application, automobile exhaust, mining and smelting processes, urbanization, agricultural activities and industrialization which contribute heavy metals into the soil environment since the study 
area lies within the metropolis (Facchineli, et al., 2001; Chen et al., 1999; Tsai et al., 2001; Shi et al., 2005, Muchuweti, et al., 2006, Tongesayi et al., 2013) which the plant absorbed together with nutrients in the course of growth.

Therefore, the aim of the study was to assess the accumulation of heavy metals in okro cultivated through irrigation along the bank of river Ngadda and Alau dam with the objective to ascertain the food safety status of the vegetable by comparing the values obtained with the FAO/WHO MPL recommended for vegetables.

\section{AIM OF RESEARCH}

To assess the level of bio-accumulation of metal pollutants in okra cultivated during dry season through irrigation with water from river Nggada and Alau Dam.

\section{OBJECTIVE}

To compare the concentration values of the heavy metals accumulated in okra with the FAO/WHO recommended MPL for consumable vegetables so as to ascertain the health risk potential

\section{MATERIALS AND METHODS}

\section{STUDY LOCATION}

The major study areas were Shekwari and Custom bridge along river Ngadda in Maiduguri municipality and at Alau dam farmland along Bama road. These areas lie between latitude $11^{\circ} 48^{\prime} \mathrm{N}$ to $11^{\circ} 52^{\prime} \mathrm{N}$ and longitude $13^{\circ} 06^{\prime} \mathrm{E}$ to 13 ${ }^{\circ} 14^{\prime} \mathrm{E}$ at an altitude of $345 \mathrm{~m}$ above sea level Figure 1. The work covers an area which is known for dry season farming of vegetables usually from the month of December to May because of the short rainy season of the region. The vegetation is of Savanna or tropical grassland with Sudan type of climate, light annual rainfall of about $864 \mathrm{~mm}$ (34inches).

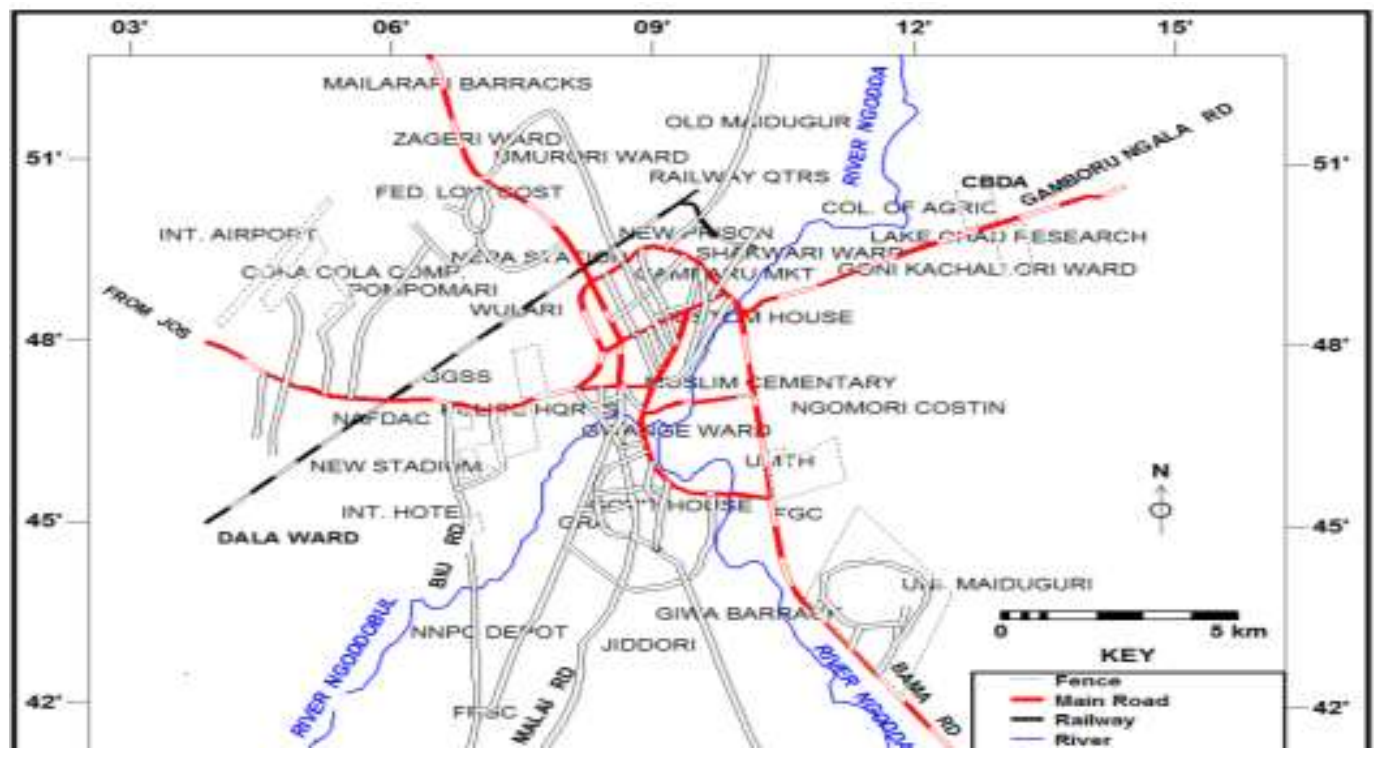

Figure 1: Maiduguri Township Map Source: Land and Survey 2012 


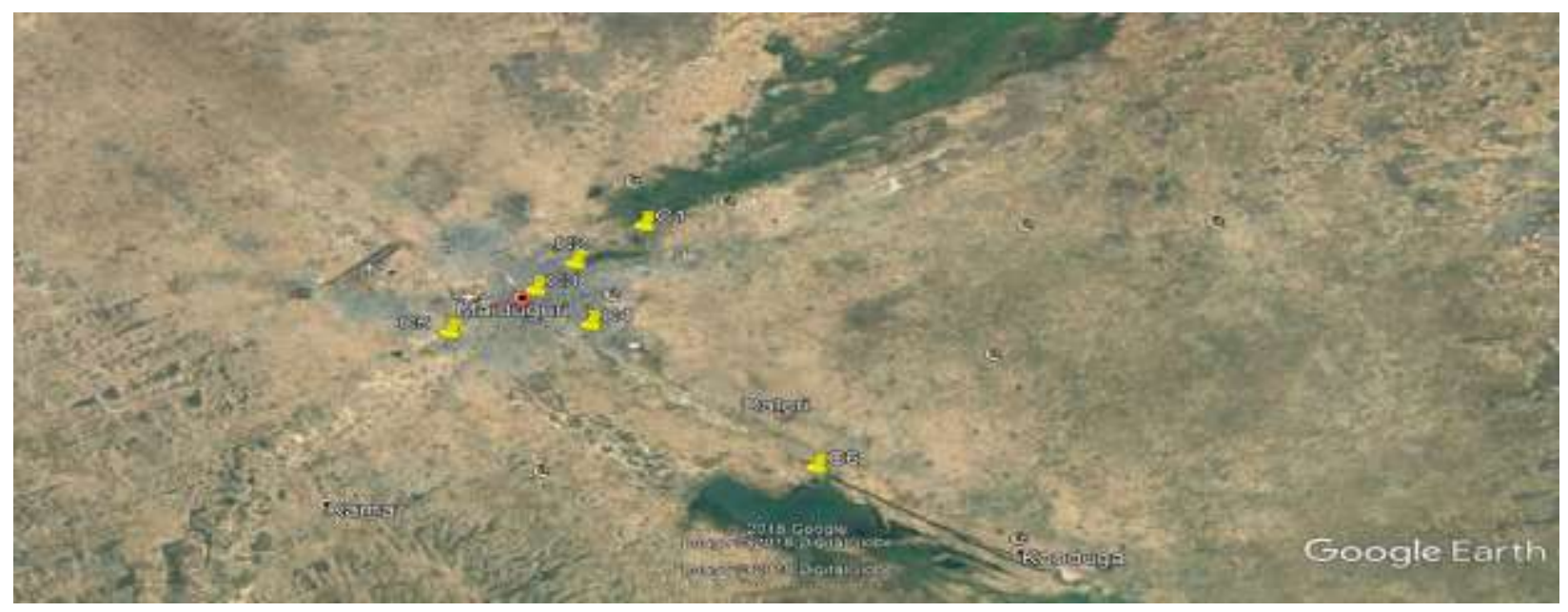

Figure 2: Okra Sample Sites Along the Bank of River Ngadda and Alau dam.

Source: Google earth

\section{SAMPLE COLLECTION}

Samples of fresh Okra were collected directly from the farm at six different locations along the bank of river Ngadda and Alau dam and labeled with codes $(\mathrm{C} 1, \mathrm{C} 2, \mathrm{C} 3, \mathrm{C} 4, \mathrm{C} 5, \mathrm{C} 6)$ Figure 2 with their ordinates Table 1.

Table 1: Ordinates of Sample Locations

\begin{tabular}{lllllll}
\hline Locations & C1 & C2 & C3 & C4 & C5 & C6 \\
\hline Ordinates & $11^{0} 52^{\prime} 40^{\prime \prime} \mathrm{N}$ & $11^{0} 43^{\prime} 25^{\prime \prime} \mathrm{N}$ & $11^{0} 49^{\prime} 55^{\prime \prime} \mathrm{N}$ & $11^{0} 48^{\prime} 60^{\prime \prime} \mathrm{N}$ & $11^{0} 48^{\prime} 17^{\prime \prime} \mathrm{N}$ & $11^{0} 43^{\prime} 18^{\prime \prime} \mathrm{N}$ \\
& $13^{0} 12^{\prime} 12^{\prime \prime} \mathrm{E}$ & $13^{0} 16^{\prime} 70^{\prime \prime} \mathrm{E}$ & $13^{0} 09^{\prime} 16^{\prime \prime} \mathrm{E}$ & $13^{0} 10^{\prime} 72^{\prime \prime} \mathrm{E}$ & $13^{0} 48^{\prime} 17^{\prime \prime} \mathrm{E}$ & $13^{0} 1663^{\prime \prime} \mathrm{E}$ \\
\hline
\end{tabular}

The okra samples were cultivated during dry season using irrigation farming process with water from the river and the dam. The locations for the sampling points were obtained using Global Positioning System (GPSs). Samples were collected at different point in an area and homogenized to constitute a sample site.

\section{SAMPLE PREPARATION}

The samples, after collection, were transported to Herbarium in Biology Department at Ahmadu Bello University, Zaria for identification and thereafter taken to laboratory, thoroughly washed with running tap water and properly rinsed with double distilled water to remove any particulate pollutants that might had adhered to the samples. They were air dried and oven dried at low temperature and there after grounded using a clean mortar and pestle and sieved to required particle sizes using a sieve that was pre-cleaned. The samples were put in sample bottles, labeled, capped, and taken to Centre for Energy Research and Training (CERT) at Ahmadu Bello University, Zaria for further preparation and analysis. 


\section{INSTRUMENTAL NEUTRON ACTIVATION ANALYSIS TECHNIQUE}

Instrumental Neutron Activation Analysis (INAA) techniques is a sensitive method for accurate determination of elemental concentration in a matrix. In this work, we employed the Nigeria Research Reactor-1 (NIRR-1) facility located at (CERT), Ahmadu Bello University Zaria, Kaduna state, Nigeria. The detail and function of NIRR-1 was obtained in the work of Jonah, et al., 2006; Jonah 2008).

Conventional method for sample preparation of vegetable samples for irradiation was adopted. The samples were put in a high density polythene vial, capped and sealed. Also Standard Reference Material (SRM) NIST) which is a direct representative of the sample was weighted of the same amount and put in the same type of vial with that of the sample, capped and sealed and both irradiated simultaneously.

\section{SAMPLE ANALYSIS}

The interaction of the sample and the neutron flux was based on the activation process expressed in Equation (1)

$\mathrm{R}=\mathcal{N} \int_{o}^{\infty} \sigma(E) \varphi(E) d E$

Where $\mathrm{R}=$ reaction rate, $\mathrm{N}=$ number of interacting isotope, $\sigma(\mathrm{E})=$ cross-section (in $\mathrm{cm}$ ) at neutron energy $\mathrm{E}$ (in $\mathrm{eV}$ ), $\omega=$ neutron flux per unit of energy $\mathrm{E}(\mathrm{eV})$ and in terms of neutron velocity the interaction was as expressed in Equation

$\mathrm{R}=\int \sigma(v) \phi^{\prime}(v) d v \infty 0=\int n(v) v \sigma(v) d v \infty 0$

Where $v$ the neutron velocity $\left(\mathrm{m} \mathrm{s}^{-1}\right), \sigma(v)$ the neutron cross section $\left(\right.$ in $\left.\mathrm{m}^{2}\right)$ for neutrons with velocity $\mathrm{v} ; n(v) d v$ the neutron density $\left(\mathrm{m}^{-3}\right)$ of neutrons with velocities between $v$ and $v+d v$, considered to be constant in time.

In this study, the relative method of neutron activation analysis for element determination in sample analysis was adopted, therefore the samples and standard were irradiated together and the induced intensities was measured. For data processing the gamma-ray spectrum analysis software WINSPAN, 2004 used by (Liyu, 2004) based on the practice of using the activity induced at time after irradiation for time $t$ was employed according to Equation (3)

$$
A_{t}=\frac{\varepsilon \sigma_{Q \rho W_{Q} \varphi}}{M_{Q}}=N_{A}\left(1-e^{-\lambda t_{i}}\right) d s^{-1}
$$

where $\mathrm{A}_{\mathrm{t}}$ is activity of element $\mathrm{Q}$ at the end of irradiation $\left(\mathrm{d}^{\mathrm{s}-1}\right), \sigma_{Q}$ is neutron capture cross section of element $\left(\mathrm{m}^{2}\right)$, $\rho$ is fractional abundance of particular isotope of element $\mathrm{Q}, \mathrm{M}_{\mathrm{Q}}$ is atomic weight of element $\mathrm{Q}$ to be measured, $N_{A}$ is Avogadro's number $\left(\mathrm{mol}^{-1}\right), \lambda$ is decay constant of induced radionuclide $\left(\mathrm{s}^{-1}\right), \mathrm{t}_{\mathrm{i}}$ is irradiation time $(\mathrm{s}), \varphi$ is is the flux of neutron used in irradiation $\left(\mathrm{nm}^{-2} \mathrm{~s}^{-1}\right)$ and $W_{Q}$ is weight of element $\mathrm{Q}$ irradiated.

The sample and standard parameters were then related by the Equation (4)

$$
\frac{A_{\text {sam }}}{A_{\text {std }}}=\frac{\phi \omega \in I N_{A}\left(1-e^{-\lambda t_{i r r}}\right) \operatorname{sam}\left(e^{-\lambda t_{d}}\right) \operatorname{sam}\left(1-e^{-\lambda t_{c}}\right) \operatorname{sam}}{\phi \omega \epsilon N_{A}\left(1-e^{-\lambda t_{i r r}}\right) \operatorname{std}\left(e^{-\lambda t_{d}}\right) \operatorname{std}\left(1-e^{-\lambda t_{c}}\right) \operatorname{std}}
$$


where $A_{\text {sam }}$ is activity of the unknown sample, $A_{\text {std }}$ is activity of the standard. Since the standard is irradiated and counted under similar conditions as the sample, common parameters in equation (4) cancelled out then the mass of the element in the sample relative to the standard comparator is calculated using equation

$$
\frac{A_{\text {sam }}}{A_{\text {std }}}=\frac{m_{\text {sam }}}{m_{\text {std }}} \frac{\left(e^{-\lambda t} d\right)}{\left(e^{-\lambda t} d\right)} \frac{s a m}{s t d}
$$

$\mathrm{m}_{\mathrm{sam}}=$ mass of element in the sample, $\mathrm{m}_{\mathrm{std}}=$ mass of element in standard,

$\lambda=$ decay constant for the isotope.

\section{RESULTS AND DISCUSSION}

The results of the concentration of the various heavy metals determined in okra samples from the various sites using INAA analytical is presented in Table 2. It was observed that the concentration values of the heavy metals varied from site to site therefore the values were grouped into three according to their magnitude of accumulation in the samples at the various site. and plotted into three graphs. This grouping was done for convenience and easy assessment only Figures $3 a-3 b$.

Table 2: Concentration of elements determined in Okra at different locations

\begin{tabular}{|c|c|c|c|c|c|c|c|c|c|c|c|}
\hline $\begin{array}{l}\text { Sample } \\
\text { Location }\end{array}$ & Al & $\mathrm{Ba}$ & $\mathrm{Cr}$ & $\mathrm{Mn}$ & $\mathrm{Fe}$ & $\mathrm{Sm}$ & $\mathrm{Sb}$ & $\mathbf{R b}$ & $\mathbf{Z n}_{\mathrm{n}}$ & $\mathrm{La}$ & Sc \\
\hline \multirow[t]{2}{*}{$\mathrm{Cl}$} & $518=13$ & $9=2.0$ & $1.1 \pm 0.2$ & $24 \pm 0.2$ & $124=30.0$ & $0.029=0.0$ & BDL & $12=1$ & $24.0=0.1$ & $0.21=0.04$ & $0.03 \neq 0.00$ \\
\hline & & & & & & 04 & & & & & 4 \\
\hline \multirow[t]{2}{*}{$\mathrm{c} 2$} & $452+19$ & $10.4 \pm 1.6$ & $1.0 \neq 0.2$ & $229=0.2$ & $219 * 35.0$ & $0.24+0.01$ & $0.13 \pm 0.03$ & $11=1$ & $24=3.0$ & $1.93 \neq 0.05$ & $0.040=0.0$ \\
\hline & & & & & & & & & & & 6 \\
\hline \multirow[t]{2}{*}{$c 3$} & $g 43=16$ & $12=1.0$ & $1.3 \pm 0.2$ & $27.8 \pm 0.2$ & $204=250$ & $0.05 \pm 0.01$ & $0,15 \pm 0.02$ & $11=1$ & $23=3.0$ & $0.30 \pm 0.03$ & $0.033 \pm 0.0$ \\
\hline & & & & & & & & & & & 0 \\
\hline \multirow[t]{2}{*}{$\mathrm{CH}$} & $437=10$ & $10=2.0$ & $1.2 \neq 0.2$ & $25.0=0.2$ & $303=36.0$ & $0.044=0.0$ & $0.26 \pm 0.03$ & $12=1$ & $8 \pm 1.0$ & $0.29=0.03$ & $0.04=0.01$ \\
\hline & & & & & & 0 & & & & & \\
\hline \multirow[t]{2}{*}{$\mathrm{Cs}$} & $477 \neq 11$ & $7 \neq 10$ & BDL & $40.2=0.2$ & $256=320$ & $0.053=0.0$ & BDL. & $7 \pm 1$ & $21=2.0$ & $0.34=0.03$ & $0.05 \neq 0.01$ \\
\hline & & & & & & 0 & & & & & \\
\hline \multirow[t]{2}{*}{ C6 } & BDL & $8 \pm 20$ & BDL. & $229 \pm 0.2$ & $1.1 \pm 0.4$ & $0.02 \pm 0.00$ & $\mathrm{BDL}$. & $13 \pm 1$ & $8 \pm 1.0$ & $0.203 \pm 0.0$ & $0.02 \pm 000$ \\
\hline & & & & & & & & & & 3 & \\
\hline LoD & 22 & 028 & 0.23 & 1.0 & 083 & 0.1 & NA & 03 & 0.12 & 0.2 & 02 \\
\hline MPL. & NA & NA & 1.3 & 2595 & 425.5 & NA & NA & $\mathrm{NA}$ & 99,4 & NA & NA \\
\hline
\end{tabular}

Al Aluminum, Ba Barium, Co Cobalt, Mn Manganese, Fe Iron, Sm Samarium, Sb Antimony, Rb Rubidium, Zn Zinc, La lanthanum, Sc Scandium

LoD: Limit of Detection

BDL: Below Detection Limit

NA: Not available

MPL: Maximum Permissible Limit

All values in part per million (ppm) 


\section{DAILY INTAKE OF METALS (DIM)}

The level of exposure from consumption of Okra vegetable investigated could be quantified using an index referred to as daily intake of metals (DIM) which was calculated using Equation (6)

$$
\mathrm{DIM}=\frac{\mathrm{M} * \mathrm{C} * \mathrm{I}}{\mathrm{W}}
$$

where $M$ is the metal concentration in the vegetable $(\mathrm{mg} / \mathrm{kg}), C$ is the conversion factor, $I$ was the estimated quantity of vegetable taken on daily basis, and $W$ is the average weight of a human being. The conversion factor of 0.085 from fresh to dry weight of vegetable was adopted from (Ge, (1992), average weights of an adult and a child were approximated to be 55.9 and $32.7 \mathrm{~kg}$ respectively, while the average quantities of vegetable taken on daily basis by adults and children were 0.345 and $0.232 \mathrm{~kg} / \mathrm{person} /$ day respectively based on reports of (Wang 2005) and (FAO/WHO.

Therefore, to estimate the health risk of any pollutant is to determine the level of exposure to that pollutant and the route(s) of exposure to a particular tissue or organ and since in this study, the daily intake of metals (DIM) was used as the exposure index, evaluation of DIM for two of the naturally abundant heavy metals Aluminum and Iron was carried out and based on the stated assumptions revealed a minimum of $2.32 \times 10^{-1} \mathrm{mg}$ and a maximum of $4.42 \times 10$

${ }^{-1} \mathrm{mg}$ for adults and a minimum of $2,63 \times 10^{-1} \mathrm{mg}$ and a maximum of $5.08 \times 10^{-1} \mathrm{mg}$ for children in the case for Aluminum and a minimum of $3.3 \times 10^{-4}$ and a maximum of $1.58 \times 10^{-1} \mathrm{mg}$ for adults and a minimum of $5.90 \times 10^{-4}$ $\mathrm{mg}$ and a maximum of $1.82 \times 10^{-1} \mathrm{mg}$ for children in the case for Iron It can be observed from the results that the daily intakes of the two heavy metals; aluminum and iron in okra for children were higher than the corresponding values for adults which imply that children tend to take in more metals than adults, and this could be due to tenderness of children's body tissues.

Figure 3a showed the graph of the concentrations of aluminum, manganese and iron determined in okra samples obtained on six farming sites along the bank of river Ngadda and Alau dam. It can be observed from the graph that at sites $\mathrm{C} 1-\mathrm{C} 5$ concentrations of $\mathrm{Al}>\mathrm{Fe}>\mathrm{Mn}$. This variation trend in concentrations could be attributed to the fact that firstly, $\mathrm{Al}$ and $\mathrm{Fe}$ are naturally abundant and secondly since the study area was predominantly within or around the municipal council, anthropogenic activities might have contributed significantly to the deposit of heavy metals in the soils used for the cultivation of the vegetable and absorbed by the plants during growth. At site $\mathrm{C} 6, \mathrm{Mn}>\mathrm{Fe}>\mathrm{Al}$, this is the reverse of the concentration value for trend of C1-C5. This variation trend could be due to the fact that site C6 was a sample site along Alau dam which was up the outskirt of Maiduguri metropolis and does not receive contaminants from the city storm therefore the soils used for the cultivation of okra had less abundance of aluminum and iron.

On comparing the concentration values of some of the heavy metals determined in okra with the values obtained in the work carried out by Chiroma et al., in 2014 with regard to Okra cultivated through irrigation with urban grey waste water in Yola the state capital of Adamawa in the north eastern part of Nigeria, Fe, Mn and $\mathrm{Zn}$ had concentrations of 883,306 and 478 ppm respectively. This values were much higher compared to the values obtained in this work. This 
could be attributed to the high concentrations of Fe, Mn and $\mathrm{Zn}$ of values 8, 2.93 and $2.4 \mathrm{ppm}$ respectively in the grey waste water used for the irrigation compared to the $0.50,0.20$ and $0.20 \mathrm{ppm}$ as the maximum allowable limit for irrigation water.

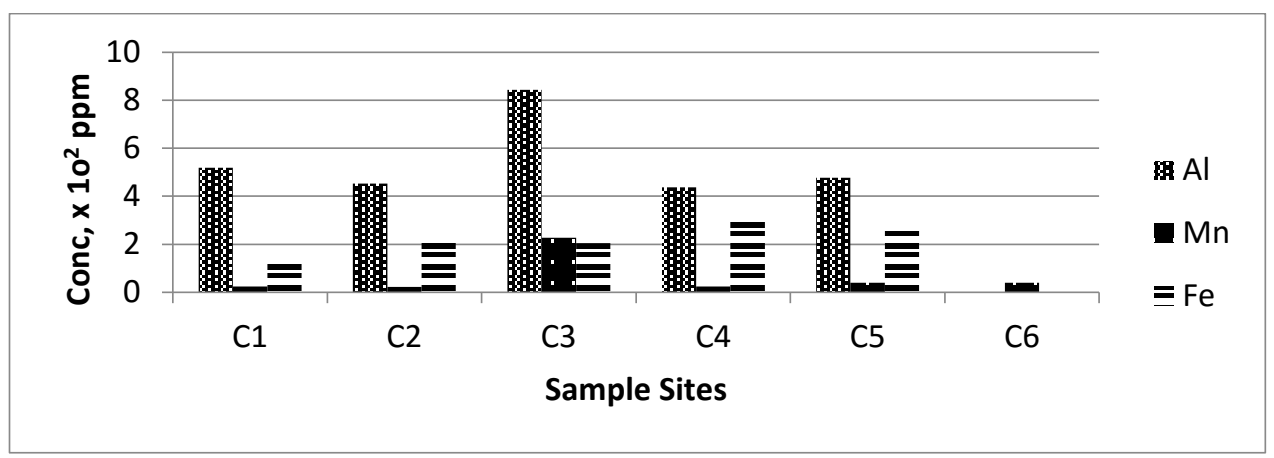

Figure 3a: Concentration of Elements Determined in okro samples

Figure $3 \mathrm{~b}$ showed the graph of concentrations of Barium, Lanthanum, Rubidium, Zinc and Chromium. It can be observed that at Site $\mathrm{C} 1-\mathrm{C} 5, \mathrm{Zn}>\mathrm{Rb}>\mathrm{Ba}$ while at $\mathrm{C} 6, \mathrm{Rb}>\mathrm{Zn}>\mathrm{Ba}$. The high values of zinc okra obtained at sites $\mathrm{C} 1$ - C5 could be due to the fact that they lied within the area where contaminants from city storm was predominant and might have mixed with soils and the water of river Ngadda therefore enhancing the concentrations of heavy metals in the soil used for the cultivation of okra vegetable.

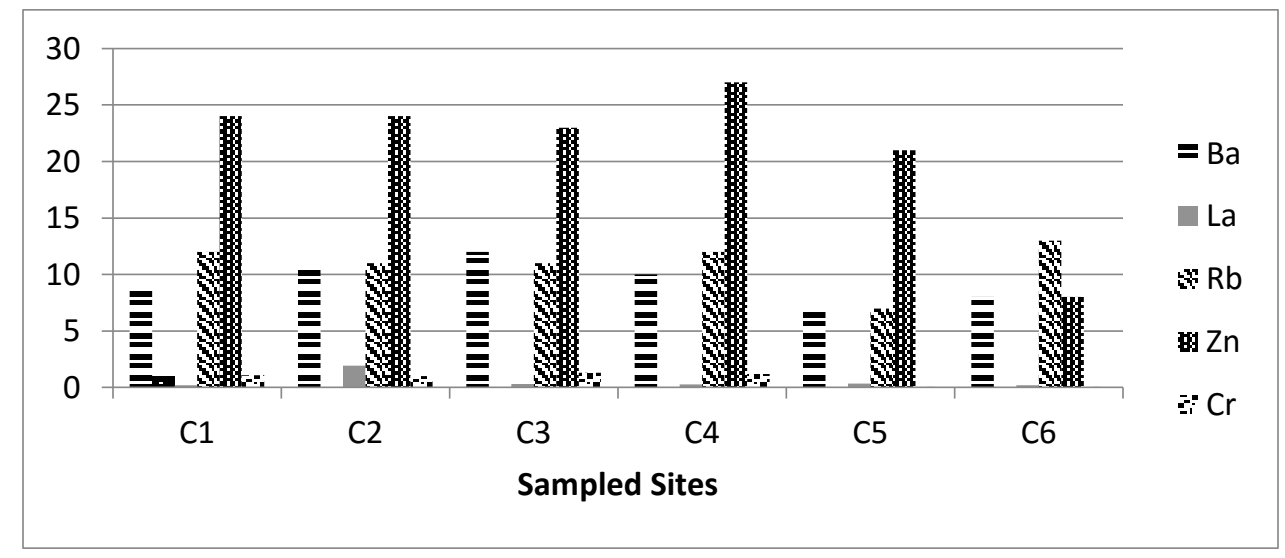

Figure 3b: Concentration of Elements Determined in okro samples

Figure 3c was the graph of Antimony, Samarium and Scandium determined in Okra samples obtained on six different sites C1- C6 along the bank of river Ngadda and Alau dam. The concentrations values of the heavy metals accumulated in okra was of the trend $\mathrm{Sb}>\mathrm{Sm}>\mathrm{Sc}$ with insignificant variation values. 


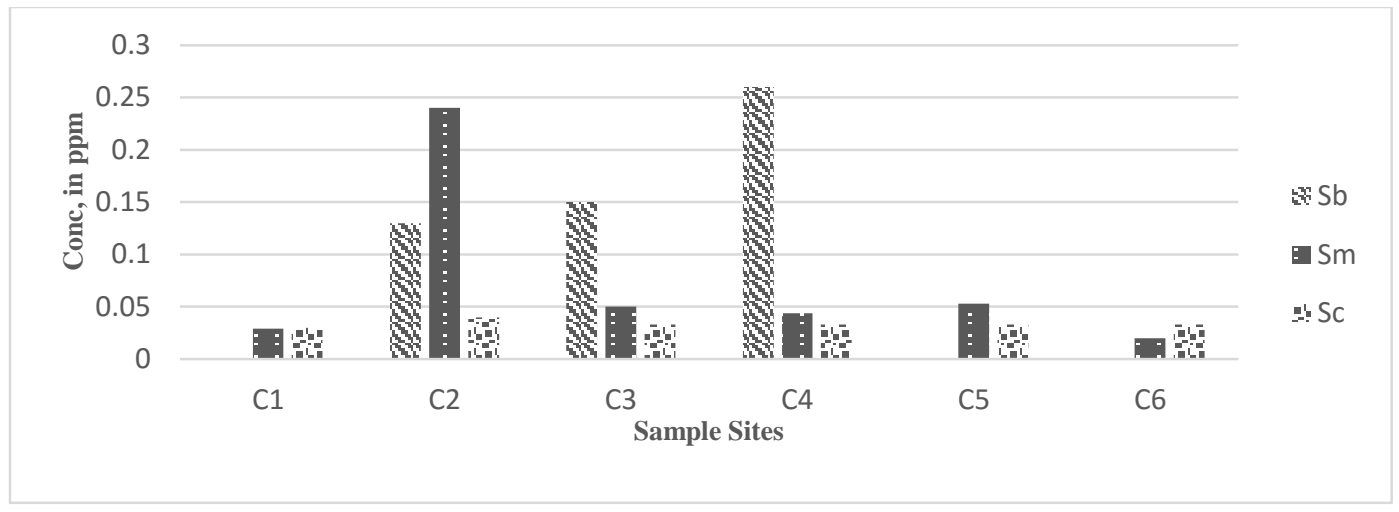

Figure 3c: Concentration of Elements Determined in okro samples

\section{CONCLUSION}

The concentrations of the heavy metals determined in Okra vegetable samples cultivated via irrigation on farmlands along the bank of river Ngadda and Alau Dam were mostly found to be within the acceptable limits recommended by FAO/WHO for vegetable besides those of manganese whose values were above the acceptable value. This result implies that the consumption of okra cultivated along the bank of river Ngada and Alau dam via irrigation during dry season constitute a public health risk due to the concentration of high level of level of manganese The heavy metals with concentrations values within recommended limit notwithstanding, does not rule out the possibility of a health risk since all heavy metals have potential to accumulate in the body and disrupt sensitive organs overtime. The study therefore recommends that regular evaluation and or monitoring of the levels of heavy metals in okra vegetables obtained from the study site be carried out even for those heavy metals found to be below the safe limit as the buildup of these elements in soil or water used for the cultivation and irrigation may increase unnoticed resulting in public health threats which only with experimental investigations that the values would be known. 


\section{REFERENCES}

Ahmed, A. S. S, Sultana, S., Habib, A., Ullah, H., Musa, N., Hossain, M. B., Mahfujur, R. M. S. and Islam, S. (2019) Bioaccumulation of heavy metals in some commercially important fishes from a tropical river estuary suggests higher potential health risk in children than adults. PLoS ONE 14(10): e0219336. https://doi.org/10.1371/journal.pone.0219336).

Asonye, C. C., Okolie, N. P., Okenwa, E. E. and Iwanyanwu, U. G. (2007): Some physicochemical Characteristics and Heavy Metal Profiles of Nigerian Rivers, Streams and Waterways. African Journal of Biotechnology 6 (5) 617624.

Chiroma, T. M., Ebewele, R. O. and Hymore, F. K. (2014): Comparative Assessment of Heay Metal Levels in Soils, Vegetables and Urban Grey Waste Water Use for Irrigation in Yola and Kano. International Referred Journalof Engineering and Science 3 (2) 1-9

Dan'azumi, B. and Bichi, M. H. (2010): Industrial Pollution and Heavy Metals Profile of Challawa River in Kano, Nigeria. Journal of Applied Sciences in Environmental Sanitation 5 (3): 23-29.

Deribachew, B. 1., Made, M. Z, Nigussie-Dechassa, R. A. M. and Taddesse, L. (2015): Selected Heavy Metals in Some Vegetables Produced Through Wastewater Irrigation and Their Toxicological Implications in Eastern Ethiopia. African Scholarly Science Trust 15 (3) 2015.

Egila, J. N., Ibrahim, E. G. and Ibrahim, M. A. G. (2014); Sequential Extraction of Lead, Copper, Zinc, Cadmium and Chromium in Soil Samples from Dumpsites in Lafia, Nasarawa State, Nigeria, Chemistry and Materials Research 6 (9) 73-80

FAO/WHO 2005: Fruits and Vegetables for Health Report of Joint FAO/WHO Workshop Kobe, Japan, September, $1-3,200439$.

Ferre-Haguet, N., Marti-Cid, R., Schuhmmacher, M. and Domingo, J. I. (2008); Risk assessment of metals from consuming vegetables, fruits, and rice grown on soils irrigated with waters of the Ebro River in Catalonia, Spain. Biological Trace Element Research 1 (23) 1-14.

Facchinelli, A., Sacchi, E. and Mallen, L. (2001): Multivariate statistical and GIS-based approach to identify heavy metal sources in soils. Environmental Pollution 114 313-324.

Ge, K. Y. (1992). The status of nutrients and meals of the Chinese in the 1990s. Beijing People's Hygiene Press, 415-434.

Hang, Z., Wen-Tao, Y., Xin, Z., Li, L, Jiao-Feng, G., Wen-Lei, W., Jia-Ling, Z., Tao, T., Pei-Qin, P. 1. and Bo-Han, L. (2016): Accumulation of Heavy Metals in Vegetable Species Planted in Contaminated Soils and the Health Risk Assessment. International Journal of Environmental Research and Public Health 13289.

Jonah, S. A., Umar, I. M., Oladipo, M. O. A. Balogun, G. I. and Adeyemo, D. J. (2006): Standardization of NIRR-1 irradiation and counting facilities for instrumental neutron activation analysis, Applied Radiation and Isotopes. 64 818-822.

Jonah, S. A. (2008): Epithermal neutron activation analysis of metal contaminants in Nigeria food additives using NIRR-1 facility, Proceedings of the $3^{\text {rd }}$ Environmental Physics Conference. $19^{\text {th }}-23^{\text {rd }}$ February 2008, Aswan Egypt.

Jibiri, N. N. and Adewuyi, G. O. (2008). Radionuclide contents and physico-chemical characterization of solid waste and effluent samples of some selected industries in the city of Lagos, Nigeria Radioprotection 43 (2) 203212. DOI: $10.1051 /$ radiopro:2007053

Khan, S., Reid, B. J., Li, G. and Zhu, Y. G. (2014): Application of biochar to soil reduces cancer risk via rice consumption: A case study in Miaoqian village, Longyan, China. Environment International 68: 154-161. 
Khan, A., Khan, S., Khan, M., AmjadQamar, Z. and Waqas, M. (2015): The uptake and bioaccumulation of heavy metals by food plants, their effects on plants nutrition and associated health risk. Environmental Science Pollution Research. 22 13772-13799.

\section{8 | Bukar and Onoja, 2020}

LWTAP (20004) Lenntech Water treatment and air purification. Water treatment. Lenntech, Rotterdamseweg, Netherlands. http:www.excelwater.com/filters/Water-Purification.htm

Liyu, W. (2004): WINSPAN 2004, A multi process Gamma-ray Spectrum Analysis Software CIAS Bejing China.

Muchuweti, M., Birkett, J. W., Chinyanga, E., Zvauya, R. and Scrimshaw, M. D. (2006): Heavy metals content of vegetables irrigated with mixture of waste water and sewage sludge in Zimbabwe: Implication for human health. Agricultural Ecosystem Environment 112 41-48.

Morton- Bermea, O., Hermandez-Alvarez, E. Gonzalez-hermandez, G., Romero, F., Lozano, R. and BeramendiOrosco, L. E. (2009): Assessment of heavy metal pollution in urban topsoil from the metropolitan area of Mexico City Journal of Geochemical Exploration 101: 218-224

Matthews-amune, C. O., Yisa, B. N. and Ukachukwu, C. V (2018): Concentration of Pb, Fe, Zn, Cu and Cd in Soil, Vegetable and Irrigation Water in Bwari Abuja, Nigeria. Journal of Appied. Science and Environmental Management 22 (9) 1443-1448.

Matorrell, I., Perello, G., Marti-Cid, R., Liobet, J. M. and Castell- Domingo, J. I. (2011): Human exposure to arsenic, cadmium, mercury and lead from foods in Catalonia, Spain: temporal trend. Biological. Trace Element. Research 142 309-322.

Mmolawa, K. B., Likuku, A. S. and Gaboutloeloe, G. K. (2011): Assessment of heavy metals in soils along major roadside areas in Botswana. African Journal of Environmental Science 5 (3) 186-196.

Nabulo, G., Black, C. R. and Young, S. D. (2011): Trace metal uptake by tropical vegetables grown on soil amended with urban sewage sludge. Environmental Pollution 159 368-376.

Oves, M., Khan, M. S., Zaidi, A. and Ahmad, E. (2012): Soil contamination, nutritive value, and human health risk assessment of heavy metals: an overview. Toxicity of Heavy Metals to Legumes and Bioremediation 1-27. Doi: 10.1007/978-3-7091-0730-0_1

Rumteke, S., Sahu, B. L., Dahariya, N. S., Patel, K. S., Blazhev, B. and Matini, L. (2016): Heavy Metal Contamination of Leafy Vegetables. Journal of Environmental Protection. 7 996-1004. http://dx.doi.org/10.4236/jep.2016.77088.

Sabina, B. (2015). The impact of waste handling on small-scale farming in Malawi Master's Thesis in Soil Science Agriculture Programme - Soil and Plant Sciences.

Singh, A., Kumar, R. S., Agrawal, M. and Marshall, F. M. (2010): Health Risk Assessment of Heavy Metals via Dietary Intake of Foodstuffs from Waste Water Irrigated Site of a Dry Tropical Area of India. Food and Chemical Toxicology. 48 (2) 611-619

Tchounwou, P. B., Clement, G. Y., Anita, K. and Dwayne, J. S. (2014): Heavy Metals Toxicity and the Environment Published in final edited form as: EXS. 2012; 101: 133-164. doi: 10.1007/978-3-7643-8340-4_6

Tongesayi, T., Fedick, P., Lechner, L., Brock, C., Beau, A. L, Bray, C. (2013): Daily bioaccessible levels of selected essential but toxic heavy metals from the consumption of non-dietary food sources. Food and Chemical Toxicology 62142-147. 
Uwah, E. I., Ndahi, P. N. and Ogugbuaja, V. O. (2009): Study of the Levels of Some Agricultural Pollutants in Soils and Water Leaf (Talinum Triangulare) Obtained in Maiduguri, Nigeria. Journal of Applied Science in Environmental Sanitation 4 (2) 71-78

Waqas, M., Li, G., Khan, S., Shamshad, J., Reid, B. J., Qamar, Z. and Chao, C. (2015): Application of Sewage Sludge and Sewage Sludge Biochar to reduce Polycyclic and aromatic hydrocarbons (PAH) and Potentially toxic elements(PTE) accumulation in Tomato. Environmental Science Pollution Research 22 12114-12123. doi; 101007/s11356-015-4432-8.

Wang, X., Sato, T., Xing, B. and Tao, S. (2005): Health Risks of Heavy Metals to the General Public in Tianjin, China via Consumption of Vegetables and Fish. Science. of the Total Environment 3 (50) 28-37. 